\title{
Effect of Infestation Density with Phelipanche aegyptiaca on the Efficiency of Bio-agent, Phytomyza orobanchia and Infestation by Tuta absoluta on Tomato Crop at El-Beheira Governorate, Egypt
}

\author{
Amany M. H. Abu-Shall ${ }^{1}$
}

\begin{abstract}
Tomato is the most susceptible hosts to many insect pests and broomrape, which causes significant yield losses. The present study was carried out with the purpose to know which infestation density of Egyptian broomrape (Phelipanche aegyptiaca Pomel) was affected on efficiency the bio-agent, Phytomyza orobanchia Kaltenbach (Diptera: Agromyzidae) in the area grown with tomato crop, which was affected at the same time by tomato leaf miner, Tuta absoluta (Meyrick) (Gelechiidae: Lepidoptera) under natural conditions during two successive years (2019 and 2020) at El-Beheira governorate, Egypt.

Three randomized fields cultivated with tomato crop in summer were selected during 2019 and 2020 . Infestation density with $P h$. aegyptiaca was divided into three levels, Low (1 - 10 shoots / plant), Medium (11 - 25 shoots / plant) and High ( $\geq 25$ shoots / plant). Number of pupae in capsules, number of pupae in stems, total number of pupae in shoots and the percentage of pupae in capsules were determined per Ph. aegyptiaca shoot. Highest effectiveness of $P$. orobanchia $(36.0 \%)$ was recorded in low infestation density with $P$. aegyptiaca, while with medium and high infestation density with $\boldsymbol{P h}$. aegyptiaca only $23.5 \%$ and $18.6 \%$, respectively in second year 2020 . No significant difference was found between low and medium infestation density with $P h$. aegyptiaca in the total number of $P$. orobanchia pupae per shoot.
\end{abstract}

At the beginning of fruiting stage of tomato crop, leaves and fruits were taken from the randomly selected tomato plants according to infestation density with $\boldsymbol{P h}$. aegyptiaca flourishes, to estimate the infestation percent by leaf miner (Tuta absoluta) throughout the two year (20192020). In addition to, percentage of parasitism by egg parasitoids of the genus Trichogramma on tomato leaf miner was determined. According to infestation density with Ph. aegyptiaca, tomato yield was calculated. At the end of this study, under the medium infestation density of Egyptian broomrape the infestation percent by $T$. absoluta was $(16.67 \%)$ synchronized with high percentage of its parasitoid, Trichogramma spp. $(63.2 \%)$ with high yield of tomato $(820 \mathrm{gm} /$ plant) compared with control (without infestation with Ph. aegyptiaca).

Obtained data may provide information for improving effective of $P$. orobanchia in biological control program of $P h$. aegyptiaca in the frame of integrated pest management (IPM) of $T$. absoluta in tomato fields. However, combining Egyptian broomrape (Ph. aegyptiaca) and $T$. absoluta in IPM program will contribute to management efficacy as well as avoid used each control methods separately for each pest. Further research is needed to choose the timing in combining between these pests to use IPM, taking into consideration efficacy, cost and environmental aspects.

Key words: Tomato, Phelipanche aegyptiaca, Phytomyza orobanchia, Tuta absoluta, Trichogramma spp.

\section{INTRODUCTION}

Tomato (Solanum lycopersicon L.) has been suffered from Orobanche species, which are obligate root-parasitic weeds widespread in Mediterranean areas, Asia, and Southern and Eastern Europe (Bayram and Çıkman, 2009; Hershenhorn et al., 2009; Salem and Abd El-Sala, 2013). Several broomrape species feed on many plant species by attaching themselves to the root hosts with haustorium to obtain nutrients and water (Lopez-Raez et al., 2008). Tomato is highly weak to three broomrape species, Phelipanche aegyptiaca Pomel (syn. Orobanche aegyptiaca), Phelipanche ramosa Pomel (syn. O. ramosa) and O. cernua Loefl. (Orobanchaceae) that are exert their greatest damage before emergence the broomrape flowering shoots from soil (Rubiales et al., 2003; Joel et al., 2007; Lopez-Raez et al., 2008; Parker, 2009). The grown tomato varieties are affected by Ph. aegyptiaca and caused the economic damage to tomato production (Kacan and Tursun, 2012). These parasitic weeds seriously affect many crops causing significant yield losses, which may occur before emergence above ground (Aksoy et al., 2004). Yield losses range was from 5\% to $100 \%$, depending on level of infestation with broomrape, host susceptibility and environmental conditions (Joel et al., 2007).

Fortunately, bio-control agent, Phytomyza orobanchia Kaltenbach (Diptera: Agromyzidae) was found associated with broomrape in tomato growing fields. $P$. orobanchia has four generations annually (Bayram and Çıkman, 2014; Al-Eryan et al., 2018). Phelipanche is attacked by the monophagous fly, $P$. orobanchia. The larvae feed only on broomrape and can reduce seed production by 30 to $90 \%$. For this reason, this fly is one of the most effective biological control agents of broomrape. But, its effectiveness may be limited by parasitoids and agricultural practices (Klein and Kroschel, 2002). 
In contrast, Tuta absoluta (Meyrick) (Gelechiidae: Lepidoptera) was first detected on tomato in 2009 at northwestern Egypt and the pest rapidly spread in different regions of Egypt (Moussa et al., 2013; Salama et al., 2015). It is oligophagous moth feeding on solanaceous crops and one of the major devastating exotic pests attacking tomato crops in many regions of the tomato producing worldwide (Germain et al., 2009). Significant damage by larvae of $T$. absoluta can potentially result to its feeding on all aerial parts of tomato plant and affects both yield and fruit quality. If T. absoluta is not properly managed, it causes $80-100 \%$ crop loss in the field and in protected cultivation (Desneux et al., 2010; Khanjani, 2013; Mansour et al., 2018). Egg parasitoids of the genus Trichogramma among the various natural enemies have received more substantial attention as potential biological control agents to T. absoluta (Cagnotti et al., 2016; Cherif et al., 2018). The parasitoid Trichogramma achaeae Nagaraja \& Nagarkatti (Hymenoptera: Trichogrammatidae) has been recorded as a successful candidate to help manage $T$. absoluta, which infests tomato crops in Mediterranean countries (Cabello et al., 2009 \&2012; Wright and Stouthamer 2011; Polaszek et al., 2012; Cascone et al., 2015; Giorgini et al., 2019).

The aim of this study is to determine the effect of infestation density with Egyptian broomrape ( $P h$. aegyptiaca) on efficiency of $P$. orobanchia, as a bioagent for broomrape and in the same time; the infestation percent by $T$. absoluta and impact of the egg parasitoid, Trichogramma spp. during two successive years (2019 and 2020) in tomato crop in order to reduce the damage caused to tomato yield under natural conditions.

\section{MATERIALS AND METHODS}

\section{1- Sites of study}

In the season of 2019, three randomized fields (about half feddan per field) were selected according to already infestation with Egyptian broomrape, Phelipanche aegyptiaca and cultivated with tomato crop, Astrin-B cultivar. Tomato was planted during mid-April in Ad Dilinjat regions " $30.8282^{\circ} \mathrm{N} 30.5329^{\circ} \mathrm{E} "$ at El-Beheira governorate, Egypt. The agricultural practices were performed with avoid insecticidal treatments during the study period. In the season of 2020 , the same work was repeated in the same regions.

\section{2- Experimental parameters}

At the flourishing time of broomrape in May, the infestation density of $P h$. aegyptiaca divided into three infestation levels in tomato fields, Low ( $1-10$ shoots / plant ), Medium ( $11-25$ shoots / plant ) and High ( $\geq$ 25 shoots / plant ). From each field, the branched broomrape ( $P h$. aegyptiaca) was picked out according to infestation level (Low, Medium and High) per tomato plant. So, 5 tomato plants were chosen per infestation level and all shoots of Ph. aegyptiaca around the plant were picked up. The collected Ph. aegyptiaca shoots were put in labeled paper packages then transferred to the laboratory.

\section{1-Estimation the efficiency of Phytomyza orobanchia}

In the laboratory, the branched broomrape inflorescences were left until $P$. orobanchia pupation occurred. To estimate the efficiency of Phytomyza population, the capsules from $P h$. aegyptiaca inflorescence were detached and classified into intact and infested capsules. Infestation percent with $P$. orobanchia / shoot was calculated. Numbers of Phytomyza pupae in capsules, stem, and total number of pupae per shoot were counted. The same work was repeated in the same regions during two year of study.

\section{2- Estimation the infestation percent by Tuta} absoluta and its egg parasitoid, Trichogramma spp.

At the beginning of fruiting stage throughout the two successive years (2019-2020), infestation leaves by tomato leaf miner, T. absoluta were taken from the randomly selected tomato plants according to infestation density with the broomrape, Ph. aegyptiaca flourishes. This leaves were put separately in sealed a polyethylene bag and examined in the laboratory under steriomicroscope for count the number of tomato leaf miner (larvae and tunnels). Also, fruits were picked carefully to estimate the leaf miner infestation. The infestation percent by leaf miner, T. absoluta in leaves and fruits were counted together per plant. In addition to, percentage of parasitism by egg parasitoid, Trichogramma spp. on T. absoluta was determined. At the end of season, tomato yield (gm) per plant was recorded in the different infestation levels with $P h$. aegyptiaca. All studied parameters were compared with control (without infestation with Ph. aegyptiaca)..

\section{3- Statistical Analysis}

The data were subjected to one-way analysis of variance (ANOVA) after appropriate transformation through an online software OP-STAT (Sheoran et al., 1998). The significantly different means were separated by LSD.

\section{RESULTS AND DISCUSSION}

The present study was carried out to determining the effect of infestation density of Egyptian broomrape (Phelipanche aegyptiaca Pomel) on efficiency of Phytomyza orobanchia, as a bio-agent for broomrape and on infestation percent by Tuta absoluta and its egg parasitoid, Trichogramma spp. in the same time. The study was carried under natural conditions in tomato fields during two successive years (2019 and 2020) at 
El-Beheira governorate, Egypt. The tomato is among the most susceptible hosts of broomrape, which causes significant yield losses, due to excessive infection in areas used to grow tomato. The broomrape, $P h$. aegyptiaca. is one of the most economically important flowering parasitic plants, which attacks various crops in the family Solanaceae, especially tomato. At the same time, T. absoluta is oligophagous moth feeding on solanaceous crops and one of the major devastating exotic pests attacking tomato crops.

\section{1- Efficiency of Phytomyza orobanchia, as a bio-agent on the Egyptian broomrape, Phelipanche aegyptiaca.}

For evaluation of $P$. orobanchia efficiency, total number of pupae (in capsules and stems) and infestation percent were used as the most important parameters. Effect of three infestation densities with Ph. aegyptiaca on efficiency of bio-agent, $P$. orobanchia in tomato fields during two years (2019-2020) is given in Table (1). In terms of all examined parameters; number of pupae in capsules, number of pupae in stem, total number of pupae per shoot and infestation percent were determined per shoot. Low infestation density with $P h$. aegyptiaca was manifested the highest efficiency, while in high infestation density with Ph. aegyptiaca was found the least efficiency. Data revealed that the infestation densities, 5-10, 11-25 and $\geq 25$ Phelipanchel tomato plant resulted 36.3, 26.3and $21.1 \%$ infestation percent with $P$. orobanchia during the first year (2019), respectively. The same trend was appeared in the second year (2020).

As a consequence of this study, the highest total number of $P$. orobanchia pupae per broomrape shoot was obtained from low infestation density with $P h$. aegyptiaca (5-10 shoots/plant) and followed by the total number of pupae per shoot from medium infestation density with Ph. aegyptiaca (11-25 shoots/plant). Considering the topic in terms of years, it was determined that the high infestation density with $P h$. aegyptiaca ( $\geq 25$ shoots/plant), caused decrease in the total number of $P$. orobanchia pupae per shoot in second year, 2020 (11.8) than the first year, 2019 (12.9) (Table. 1).

The efficiency of $P$. orobanchia increased significantly by decreasing the number of Egyptian broomrape shoots (low infestation density with $P h$. aegyptiaca). While, no significant difference between low and medium infestation density with $P h$. aegyptiaca in the total number of $P$. orobanchia pupae per broomrape shoot, which important to re- release of Phytomyza pupae in biological control of $P h$. aegyptiaca. during successive seasons.

In line with the findings obtained in the current study, Piwowarczyk et al. (2018) reported that the infestation of Phelipanche ramosa by $P$. orobanchia in tomato crops was observed in the form of mining in flowers (ovary with seeds), shoots, and tubers. A single broomrape plant could be parasitized by 1 to 10 larvae. Bayram and Çıkman (2014) observed that the density of $P$. orobanchia in each part of broomrape may also change according to broomrape vegetation in lentil and tomato fields. In case of low density of broomrape, more than one larva or pupa (2-4) could be seen in the same capsule. The $P$. orobanchia females prefer fresh and suitable capsules for egg laying and for feeding. When $P$. orobanchia couldn't find suitable capsules, especially when a new broomrape emerge or when plants are getting older and dryer, then $P$. orobanchia lays eggs in fresh shoots and stems. The $P$. orobanchia life cycle depends on fresh broomrape parts, so any part of broomrape has more suitable water and food, females laying their eggs inside it (Bayram and Çıkman, 2016) to sustain its generation (Bayram and Çıkman, 2009). On the contrary, according to a survey study carried out by Aksoy et al., (2004), P. orobanchia was only found in lentil fields with a very low population, while couldn't find in bean and tomato fields.

When the amount of broomrape in the field is high, the activity of $P$. orobanchia on per broomrape will be lower, but if the amount of broomrape is low or broomrape has fewer capsules, the activity of $P$. orobanchia on per broomrape will be higher. It is completely depend on density of host and parasitoid. Anyway, when infestation level of broomrape is minimal or moderate; it is enough to control broomrape by $P$. orobanchia. (Bayram and Ç1kman, 2016 and 2017). Although several potential control measures have been developed in the past decades for tomato crop, any single approach is often only partially effective and sometimes inconsistent and affected by environmental conditions. Therefore, the most feasible way of coping with the weedy root parasites is via the integration of a variety of measures in an integrated management approach to prevent the damage caused by this weedy parasite (Hershenhorn et al., 2009).

Future studies should focus on protecting the last generation of $P$. orobanchia in broomrape remains then collecting and releasing them at the beginning of subsequent season. The existence and efficiency of $P$. orobanchia are a source of sight for any subsequent biological control studies. Therefore, protection of $P$. orobanchia population from harmful agriculture practices is necessary. However, releasing of $P$. orobanchia individuals should be made periodically for many years in infested fields. The broomrape fly, $P$. orobanchia is a hopeful agent for controlling broomrape and for integrating with other control methods. The awareness of farmers should be raised about the beneficial role of this biological control agent and about the seriousness of the heavy treatments by pesticides. 


\section{2- Infestation percent by Tuta absoluta and parasitism by egg parasitoid, Trichogramma spp.}

In terms of the percentage infestation of $T$. absoluta, the high infestation density of broomrape was correlated with the low infestation percent of $T$. absoluta (11.67 and 10.87\%). In contrast, it was correlated with raising in the percentage of parasitism by its parasitoid, Trichogramma spp. (68.1 and 68.8\%) per plant during two years, respectively. While, the control (without infestation with $P h$. aegyptiaca) was determined as generating the highest infestation percent by T. absoluta ( $42.67 \%$ and $49 \%$ ) in two years 2019 and 2020 , respectively. In contrast, the percentage of its parasitoid, Trichogramma spp. was low $(50.2 \%$ and $51.2 \%$ ) during two years, respectively. On the other trend, the infestation percent by $T$. absoluta was observed to be moderate in both of the low and medium infestation density with broomrape flourishes, $P h$. aegyptiaca and the percentage of parasitism by its egg parasitoid, Trichogramma spp. was high. No significant differences were found between low and medium infestation density with $P h$. aegyptiaca in the percentage of parasitism by Trichogramma spp. on $T$. absoluta per plant (Table. 2).

The tomato leaf miner, T. absoluta is an invasive species threatening tomato crops. Most of T. absoluta control strategies are still based on insecticide use (Lietti et al., 2005; Guedes and Picanço, 2012), the effectiveness of which is often undermined by insecticide resistance (Silva et al., 2011; Roditakis et al., 2018; Silva et al., 2019) and/or reduced contact with the larvae hidden inside plant stems or fruits (Cocco $e t$ al., 2013). Since most insecticides have become ineffective to control $T$. absoluta, effective and environmentally friendly alternatives are needed. Biological control by parasitoids, Trichogramma spp. is an effective means of reducing this pest (Schäfer and Herz, 2020). As reviewed by previous authors who studied the percentages of parasitism by different Trichogramma spp. against different hosts (Chailleux et al., 2012; Cabello et al., 2012), was close to (65.9$91.74 \%)$. Host parasitism by different egg parasitoids (62.56-84.22\%) against T. absoluta, obtained in the study by (Manohar et al., 2019).

In terms of the infestation with Ph. aegyptiaca inflorescence in tomato fields and attract natural enemies, Cloyd (2020) noted that the biological control can be also applied by providing flowering plants that will attract natural enemies. However, based on the scientific literature, that providing natural enemies with floral resources will result in an abundance of natural enemies sufficient to management insect pest populations below economically injury levels. Different researches showed that parasitoid, T. achaeae was innately attracted to volatiles produced by tomato plants, whether uninfested or infested by T. absoluta. However, egg parasitoids (Trichogramma spp.) could not distinguish between volatiles from uninfested or $T$. absoluta-infested tomato plants (Gontijo et al., 2019). To further increase this parasitoid efficiency, it is important to study the chemical ecology of trophic interactions among tomato plants, T. absoluta, and its parasitoid, T. achaeae. While it is known that $T$. absoluta eggs and larvae can elicit the production of HIPVs (Herbivore-induced plant volatiles) by tomato plants (Backer et al., 2015; Anastasaki et al., 2018). The responses of Trichogramma spp. to HIPVs remain unexplored. Likewise, it is unknown if Trichogramma spp. females could be attracted to $T$. absoluta according to HIPVs from tomato crop only or flourished broomrape also. The pursuit of such knowledge is crucial to improve the effective use of Trichogramma spp. in the augmentative biological control of $T$. absoluta in tomato fields. Results and implications are requiring further studies in the context of sustainable $T$. absoluta management.

\section{3- Tomato Yield}

Considering the topic in terms of years, it was determined that the high infestation density with $P h$. aegyptiaca $(\geq 25$ shoots/plant), caused significantly losses in tomato yield annually. In the high infestation density with $P h$. aegyptiaca, a decrease in the tomato yield $(\mathrm{gm})$ per plant was determined from the first year (2019) $(450 \mathrm{gm} / \mathrm{plant})$ to $(420 \mathrm{gm} / \mathrm{plant})$ in the second year (2020) (Table. 2). Tomato yield significantly differ according to infestation density with $P h$. aegyptiaca (low, medium and high). Also, considerable decreases are observed in the tomato yield due to infestation percent by $T$. absoluta, when compared to control (without infestation with $P h$. aegyptiaca). Tomato yield was low in control may be according to high infestation percentage by $T$. absoluta and low infestation percentage by Trichogramma spp. On the other hand, Tomato yield was low in the high infestation density with broomrape, Ph. aegyptiaca, although the infestation percentage by Tuta absoluta was low and infestation percentage by Trichogramma spp. was very high in the two years 2019 and 2020 (Table. 2). 
Table 1. Effect of three infestation densities with Phelipanche aegyptiaca on efficiency of bio-agent, Phytomyza orobanchia in tomato fields during two years (2019-2020) at El-Beheira governorate, Egypt

\begin{tabular}{|c|c|c|c|c|c|c|c|c|}
\hline \multirow[t]{2}{*}{$\begin{array}{l}\text { Infestation density } \\
\text { with } P \text { Ph. aegyptiaca } \\
\text { / tomato plant }\end{array}$} & \multicolumn{2}{|c|}{$\begin{array}{l}\text { No. of pupae in } \\
\text { Ph. aegyptiaca } \\
\text { capsules / shoot }\end{array}$} & \multicolumn{2}{|c|}{$\begin{array}{l}\text { No. of pupae inside } \\
\text { Ph. aegyptiaca } \\
\text { stems / shoot }\end{array}$} & \multicolumn{2}{|c|}{$\begin{array}{c}\text { Total number of } \\
P . \text { orobanchia } \\
\text { pupae/shoot }\end{array}$} & \multicolumn{2}{|c|}{$\begin{array}{l}\text { Infestation percent } \\
\text { with } P \text {. orobanchia / } \\
\text { Ph. aegyptiaca } \text { shoot }\end{array}$} \\
\hline & 2019 & 2020 & 2019 & 2020 & 2019 & 2020 & 2019 & 2020 \\
\hline $\begin{array}{c}\text { Low Infestation } \\
(5-10 \text { shoots / plant })\end{array}$ & $9.2 \mathbf{a}$ & $9.1 \mathbf{a}$ & $14.7 \mathbf{a}$ & $14.00 \mathbf{a}$ & $23.9 \mathbf{a}$ & $23.1 \mathbf{a}$ & $36.3 \mathbf{a}$ & $36.0 \mathbf{a}$ \\
\hline $\begin{array}{l}\text { Midium Infestation } \\
(11-25 \text { shoots / plant })\end{array}$ & $6.8 \mathbf{b}$ & $6.6 \mathrm{~b}$ & $11.8 \mathbf{b}$ & $11.2 \mathbf{b}$ & $18.6 \mathbf{a}$ & $17.8 \mathbf{a}$ & $26.3 \mathbf{b}$ & $23.5 \mathbf{b}$ \\
\hline $\begin{array}{l}\text { High Infestation } \\
(\geq 25 \text { shoots / plant })\end{array}$ & $4.5 \mathrm{c}$ & $4.1 \mathrm{c}$ & $8.4 \mathrm{c}$ & $7.7 \mathbf{c}$ & $12.9 \mathbf{b}$ & $11.8 \mathbf{b}$ & $21.1 \mathrm{c}$ & $18.6 \mathrm{c}$ \\
\hline LSD 0.01 & \multicolumn{2}{|c|}{2.2} & \multicolumn{2}{|c|}{2.6} & \multicolumn{2}{|c|}{5.5} & \multicolumn{2}{|c|}{4.8} \\
\hline
\end{tabular}

Means within a row sharing the same letter are not significantly different at LSD $=0.01$

Table 2. Effect of three infestation densities with Phelipanche aegyptiaca on infestation percent by Tuta absoluta and its egg parasitoid, Trichogramma spp. in tomato fields during two years (2019-2020) at El-Behira governorate, Egypt

\begin{tabular}{|c|c|c|c|c|c|c|}
\hline \multirow{2}{*}{$\begin{array}{c}\text { Infestation density with } \\
\text { Phelipanche aegyptiaca / } \\
\text { tomato plant }\end{array}$} & \multicolumn{2}{|c|}{$\begin{array}{l}\text { Infestation percent by } \\
\text { Tuta absoluta / plant }\end{array}$} & \multicolumn{2}{|c|}{$\begin{array}{l}\text { Percentage of parasitism } \\
\text { by Trichogramma spp. } \\
\text { on Tuta absoluta / plant }\end{array}$} & \multicolumn{2}{|c|}{$\begin{array}{l}\text { Tomato yield / plan } \\
(\mathrm{gm} / \text { plant })\end{array}$} \\
\hline & 2019 & 2020 & 2019 & 2020 & 2019 & 2020 \\
\hline $\begin{array}{c}\text { Low Infestation } \\
(5-10 \text { shoots / plant })\end{array}$ & $23.67 \mathbf{b}$ & $22.67 \mathbf{b}$ & $60.1 \mathrm{~b}$ & $60.4 \mathbf{b}$ & $650 \mathbf{a}$ & $690 \mathbf{a}$ \\
\hline $\begin{array}{c}\text { Midium Infestation } \\
(11-25 \text { shoots / plant })\end{array}$ & $17.33 \mathbf{c}$ & $16.67 \mathrm{c}$ & $61.8 \mathbf{b}$ & $63.2 \mathbf{b}$ & $800 \mathbf{a}$ & $820 \mathbf{a}$ \\
\hline $\begin{array}{c}\text { High Infestation } \\
(\geq 25 \text { shoots / plant })\end{array}$ & $11.67 \mathrm{~d}$ & $10.87 \mathbf{d}$ & $68.1 \mathbf{a}$ & $68.8 \mathbf{a}$ & $450 \mathrm{~b}$ & $420 \mathbf{b}$ \\
\hline $\begin{array}{c}\text { Control } \\
\text { (without infestation with } \\
\text { Phelipanche aegyptiaca) }\end{array}$ & $42.67 \mathbf{a}$ & $49.0 \mathbf{a}$ & $50.2 \mathbf{c}$ & $51.2 \mathrm{c}$ & $470 \mathrm{~b}$ & $440 \mathbf{b}$ \\
\hline LSD 0.01 & 4.25 & 4.84 & 5.2 & 5.4 & 160 & 140 \\
\hline
\end{tabular}

Means within a row sharing the same letter are not significantly different at LSD $=0.01$

\section{CONCLUSION}

Although variety studies are available carried out in order to prevent broomrape and $T$. absoluta development in tomato growing, no study has been found concerning the effect of broomrape and $T$. absoluta together as a serious pests in tomato fields. Obtained data may provide valuable information for improving effective of Phytomyza orobanchia in biological control program of Phelipanche aegyptiaca in the frame of integrated pest management (IPM) of Tuta absoluta in tomato fields. However, combining these pests in IPM program will contribute to management efficacy as well as avoid used each control methods separately for each pest. Further research is needed to choose the timing in combining between these pests to use IPM, taking into consideration efficacy, cost and environmental aspects.

\section{REFERENCES}

Aksoy, E., S. Öztemiz and F. N. Uygur. 2004. Determination of natural enemies of Orobanche species and investigation of biological control possibilities by using Phytomyza orobanchia Kalt. (Diptera: Agromyzidae) as a biological agent against Orobanche spp., in Çukurova region of Turkey. I. Plant Protection Congress. 8-10 September, Samsun.

Al-Eryan, M. A. S., A. M. H. Abu-Shall and A. H.Ibrahim. 2018. Determination of annual generations of Phytomyza orobanchia Kalt. (Diptera: Agromyzidae), using growing degree-days in Alexandria region, Egypt. Egyptian J. of Biological Pest Control. 28(96): 1-6.

Anastasaki, E., F.Drizou and P. G. Milonas. 2018. Electrophysiological and oviposition responses of Tuta absoluta females to herbivore-induced volatiles in tomato plants. J. of Chemical Ecology. 44: 288-298. https ://doi.org/10.1007/s1088 6-018-0929-1 
Bayram, Y. and E.Ç1kman. 2009. Investigation on Orobanche spp. which are harmful in lentil and tomato fields and efficiency of Phytomyza orobanchia Kaltenbach (Diptera: Agromyzidae) on Orobanche spp. in Diyarbakır and Mardin provinces. Oral presentation. III. Plant Protection Congress. Van- Turkey.

Bayram, Y. and E. Çıkman. 2014. An investigation of Broomrape species (Orobanche spp.) in lentil and tomato fields, and infestation and density of Phytomyza orobanchia Kaltenbach (Diptera: Agromyzidae) on Broomrape species, in Diyarbakır Province. Turkish J. of Biological control. 5 (2): 121-136. ISSN 2146-0035 Original article.

Bayram, Y. and E.Çikman. 2016. Efficiency of Phytomyza orobanchia Kaltenbach (Diptera: Agromyzidae) on Orobanche crenata Forsk. (Orobanchaceae) in Lentil Fields at Diyarbakir and Mardin Provinces, Turkey. Egyptian J. of Biological Pest Control. 26(2): 365-371.

Bayram, Y. and E.Çikman. 2017. Investigation of Efficiency of Phytomyza orobanchia Kaltenbach (Diptera: Agromyzidae) on Orobanche aegyptiaca Pers. and $O$. ramosa Linnaeus (Orobanchaceae) in Tomato Fields at Diyarbakir and Mardin Provinces. J. of Tekirdag Agricultural Faculty. 14(2): 16-21.

Cabello, T., J. R.Gallego, E.Vila, A.Soler, M.del Pino and A. Carnero. 2009. Biological control of the South American tomato pinworm, Tuta absoluta (Lepidoptera: Gelechiidae), with releases of Trichogramma achaeae (Hym.: Trichogrammatidae) in tomato greenhouses of Spain. IOBC/WPRS Bull. 49:225-230.

Cabello, T., J. R.Gallego, F. J.Fernandez, M.Gamez, E.Vila, M. del Pino and E.Hernandez-Suarez. 2012. Biological control strategies for the South American tomato moth (Lepidoptera: Gelechiidae) in greenhouse tomatoes. J. of Economic Entomology. 105(6):2085-2096.

Cagnotti, C. L., C. M.Hernández, A. V.Andormo, M.Viscarret, M.Riquelme, E. N. Botto and S. N. López. 2016. Acceptability and suitability of Tuta absoluta eggs from irradiated parents to parasitism by Trichogramma nerudai and Trichogramma pretiosum (Hymenoptera: Trichogrammatidae). Agricultural of Forest Entomology. 18:198-205.

Cascone, P., S.Carpenito, S.Slotsbo, L.Iodice, G. J.Sørensen, M.Holmstrup and E.Guerrieri. 2015. Improving the efficiency of Trichogramma achaeae to control Tuta absoluta. Biocontrol. 60:761-771.

Chailleux, A., N. Desneux, J.Seguret, H. Do Thi Khanh, P. Maignet and E. Tabone. 2012. Assessing European egg parasitoids as a mean of controlling the invasive South American tomato pinworm Tuta absoluta. PLOS ONE. 7(10): e48068. https://doi.org/10.1371/j.pone.0048068

Cherif, A., R. Mansour, S.Attia-Barhoumi, L.Zappalà and K. Grissa-Lebdi. 2018. Effectiveness of different release rates of Trichogramma cacoeciae (Hymenoptera: Trichogrammatidae) against Tuta absoluta (Lepidoptera: Gelechiidae) in protected and open field tomato crops in Tunisia. Biocontrol Sci. and Technology. 29: 149-161. https://doi.org/10.1080/09583 157.2018.1542485
Cloyd, R. A. 2020. How Effective is conservation biological control in regulating insect pest populations in organic crop production systems?. Insects. 11(744): 1-15. doi:10.3390/insects11110744

Cocco, A., S. Deliperi and G. Delrio. 2013. Control of Tuta absoluta (Meyrick) (Lepidoptera: Gelechiidae) in greenhouse tomato crops using the mating disruption technique. J. of Applied Entomology. 137:16-28.

Desneux, N., E.Wajnberg, K. A. G.Wyckhuys, G.Burgio, S.Arpaia, C. A.Narváez-Vasquez, J.González-Cabrera, D.Catalán Ruescas, E.Tabone, J.Frandon, J.Pizzol, C.Poncet, T. Cabello and A.Urbaneja. 2010. Biological invasion of European tomato crops by Tuta absoluta: ecology, geographic expansion and prospects for biological control. J. of Pest Sci. 83(3): 197-215.

Germain, J. F., A. I. Lacordaire, C. E. Cocquemopt, J. M. Ramel and E.Qudaed. 2009. Un nouveau ra vaguer. De la tomate en france: Tuta absoluta PHN. Revue Horticole. 512:37-41.

Giorgini, M., E.Guerrieri, P. Cascone and L. Gontijo. 2019. Current strategies and future outlook for managing the Neotropical tomato pest Tuta absoluta (Meyrick) in the Mediterranean Basin. Neotropical Entomology. 48: 1-17. https ://doi.org/10.1007/s1374 4-018-0636-1

Gontijo, L., P.Cascone, M.Giorgini, M.Michelozzi, H. S.Rodrigues, G.Spiezia, L.Iodice and E. Guerrieri. 2019. Relative importance of host and plant semiochemicals in the foraging behavior of Trichogramma achaeae, an egg parasitoid of Tuta absoluta. J. of Pest Sci. 92:1479-1488. https://doi.org/10.1007/s10340-019-01091-y

Guedes, R. N. C. and M. C. Picanço. 2012. The tomato borer Tuta absoluta in South America: pest status, management and insecticide resistance. EPPO Bull. 42:211-216.

Hershenhorn, J., H. Eizenberg, E. Dor, Y.Kapulnik and Y. Goldwasser. 2009. Phelipanche aegyptiaca management in tomato. Weed Research. 49: 34-37.

Joel, M. D., J.Hershenhorn, H.Eizenberg, R.Aly, G.Ejeta, P. J.Rich, J. K. Ransom, J.Saverborn and D.Rubiales. 2007. Biology and management of weedy root parasites. Horticultural Reviews. 33: 267-350.

Kacan, K. and N. Tursun. 2012. Effect of planting time and tomato varieties on Broomrape (Phelipanche aegyptiaca) emergence and tomato yield in western Turkey. Research on Crops. 13 (3): 1070-1077.

Khanjani, M. 2013. Vegetable pest in Iran, 5nd Edition, BuAli Sina University Press Center, Iran. pp.467.

Klein, O. and J. Kroschel. 2002. Biological control of Orobanche spp. with Phytomyza orobanchia, a review. Biocontrol. 47: 245-277.

Lietti, M. M. M., E.Botto and R. A.Alzogaray. 2005. Insecticide resistance in argentine populations of Tuta absoluta. Neotropical Entomology. 34:113-119. 
Lopez-Raez, J. A., T.Charnikhova, V.Gomez-Roldan, R.Matusova, W.Kohlen, R. D.Vos, F.Verstappen, V.Puech-Pages, G.Becard, P.Mulder and H. Bouwmeester. 2008. Tomato strigolactones are derived from carotenoids and their biosynthesis is promoted by phosphate starvation. New Phytologist. 178 : 863-74.

Manohar, T. N., P. L.Sharma, S. C. Verma and R. S. Chandel. 2019. Demographic parameters of the indigenous egg parasitoids, Trichogramma spp., parasitizing the invasive tomato leaf miner, Tuta absoluta (Meyrick) (Lepidoptera: Gelechiidae). Egyptian J. of Biological Pest Control. 29(9): 1-8. https://doi.org/10.1186/s41938-019-0112-1

Mansour, R., T.Brévault, A. Chailleux, A.Cherif, K. G.Lebdi, K.Haddi, S. A.Mohamed, R. S.Nofemela, A.Oke, S.Sylla, H. E. Z.Tonnang, L.Zappalà, M. Kenis, N. Desneux and A.Biondi. 2018. Occurrence, biology, natural enemies and management of Tuta absoluta in Africa. Entomologia Generalis. 38 (2): 83-112.

Moussa, S., A.Sharma, F.Baiomy and F. E. El-Adl. 2013. The status of tomato leaf miner Tuta absoluta (Meyrick) (Lepidoptera: Gelechiidae) in Egypt and potential effective pesticides. Academic J. of Entomology. 6: 110 115.

Parker, C. 2009. Observation on the current status of Orabanche and Striga problems worldwide. Pest Management Sci. 65: 453-59.

Piwowarczyk, R., Ł.Mielczarek and S.Guzikowski. 2018. Scientific Notes: First report of Phytomyza orobanchia (Diptera: Agromyzidae) from Poland and Chymomyza amoena (Diptera: Drosophilidae) on Phelipanche ramose (Orobanchaceae). Florida Entomologist. 101(3): 540-542.

Polaszek, A., P. F.Rugman-Jones, R.Stouthamer, E. Hernandez-Suarez and T. Cabello. 2012. Molecular and morphological diagnoses of five species of Trichogramma: biological control agents of Chrysodeixis chalcites (Lepidoptera: Noctuidae) and Tuta absoluta (Lepidoptera: Gelechiidae) in the Canary Islands. Biocontrol. 57:21-36.
Roditakis, E., E.Vasakis, L.Garcīa-Vidal, M. D .R.MartīnezAguirre, J. L.Rison, M. O.Haxaire-Lutun, R.Nauen, A.Tsagkarakou and P.Bielza. 2018. A four-year survey on insecticide resistance and likelihood of chemical control failure for tomato leaf miner Tuta absoluta in the European/Asian region. J. of Pest Sci. 91:421-435. https ://doi.org/10.1007/s1034 0-017-0900-X

Rubiales, D., A.Perez-de-Luque, J. I. Cubero and J. C. Sillero. 2003. Crenate broomrape (Orobanche crenata) infection in field pea cultivars. Crop Protection. 22: 865-872.

Salem, S. A. and A. M. E.Abd EL-Sala. 2013. Prospects for the bio-control agent of the parasitic weeds, Orobanche crenata Forsk. on some vegetable host plants in Egypt. Canadian J. of Plant Protection (CJPP). 1 (3) ISSN: 22913254

Salama, H. S. A., I. A.Ismail, M.Fouda, I.Ebadah and I.Shehata. 2015. Some ecological and behavioral aspects of the tomato leaf miner Tuta absoluta (Meyrick) (Lepidoptera: Gelechiidae). J. of Balkan Ecology. 7: 3544.

Schäfer, L. and A.Herz. 2020. Suitability of European Trichogramma species as biocontrol agents against the tomato leaf miner Tuta absoluta. Insects. 11(357):1-18. doi:10.3390/insects11060357

Sheoran, O. P., D. S.Tonk, L. S.Kaushik, R. C. Hasija and R. S. Pannu. 1998. Statistical software package for agricultural research workers. In: Hooda DS, Hasija RC (eds) Recent advances in information theory, statistics \& computer applications. Department of Mathematics Statistics, CCS HAU, Hisar. 139-143.

Silva, G. A., M. C.Picanço, L.Bacci, A. L. B.Crespo, J. F. Rosado and R. N. C. Guedes. 2011. Control failure likelihood and spatial dependence of insecticide resistance in the tomato pinworm, Tuta absoluta. Pest Management Sci. 67: 913-920.

Silva, J. E., L. M.S.Ribeiro, N.Vinasco, R. N. C. Guedes and H. A. A. Siqueira. 2019. Field-evolved resistance to chlorantraniliprole in the tomato pinworm Tuta absoluta: inheritance, cross-resistance profile, and metabolism. J. of Pest Sci. 92: 1421-1431. https://doi.org/10.1007/s1034 $\underline{0-018-1064-\mathrm{Z}}$

Wright, M. G. and R. Stouthamer. 2011. First report of Trichogramma achaeae (Hymenoptera: Trichogrammatidae) from Hawaii. Proceedings of the Hawaiian Entomological Society.43: 67. 


\title{
الملخص العربي
}

\section{تأثثر كثافة الإصابة بالهالوك Phelipanche aegyptiaca على كفاءة العنصر الحيوي}

\section{Phytomyza orobanchia}

\author{
البحيرة ، مصر \\ أمانى مصطفى حسن ابوشال
}

في بداية مرحلة الإثمار لمحصول الطماطم ، تم أخذ الأوراق والثمار من نباتات الطماطم المختارة عشوائيًا وفقًا لكثافة الإصابة بنورات الهالوك Ph. aegyptiaca ، لتقدير نسبة الإصابة بنافقة أوراق الطماطم (Tuta absoluta) طوال العامين

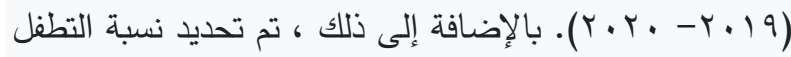
بطفيليات البيض من جنس Trichogramma على نافقة أوراق الطماطم. كما تم حساب محصول الطماطم وفقا لكثافة الإصابة للهالوك Ph. aegyptiaca. وفي نهاية هذه الدراسة، وجد تحت كثافة الإصابة المتوسطة بالهالوك المصري كانت نسبة الإصابة

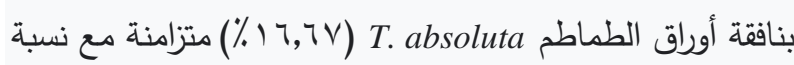

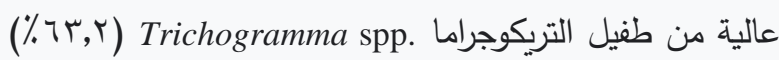

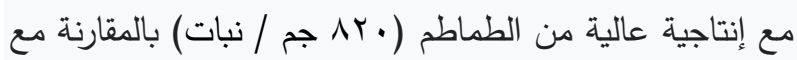
الكنترول (بدون إصابة بالهالوك (Ph. aegyptiaca). قد توفر البيانات التي تم الحصول عليها معلومات لتحسين فعالية العنصر الحيوى P. orobanchia في برنامج المكافحة البيولوجية للهالوك Ph. aegyptiaca في إطار الإدارة المتكاملة للآفات (IPM) لحشرة T. absoluta في حقول الطماطم. ومع ذللك، فإن الجمع بين الهالوك المصري Ph. aegyptiaca و absoluta فعالية الإدارة وكذلك تجنب استخدام كل طريقة مكافحة على بلى حدة لكل آفة. وهناك حاجة إلى مزيد من البحث لاختيار توقيت الجمع بين هذه الآفات لاستخدام المكافحة المتكاملة للآفات، مع مراعاة الفعالية والتكلفة والجوانب البيئية.
محصول الطماطم هو أكثرالعوائل النباتية حساسية للعديد من الآفات الحشرية والهالوك broomrape ، والتي تسبب خسائر كبيرة في المحصول. أجريت هذه الدراسة بهدف معرفة كثافة Phelipanche aegyptiaca ( الإصابة بالهالوك المصري Phytomyza الذى يؤثر على كفاءة العنصر الحيوي Pomel في (Agromyzidae : Diptera) orobanchia Kaltenbach المنطقة المزروعة بمحصول الطماطم، والتى تأثرت في نفس : الوقت بنافقة أوراق الطماطم Tuta absoluta (Meyrick) في ظل الظروف الطبيعية خلال (Gelechiidae: Lepidoptera)

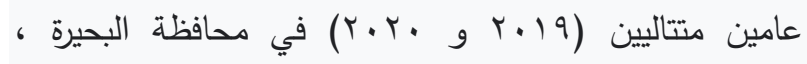
تم اختيار ثلاثة حقول عشوائية مزروعة بمحصول الطماطم

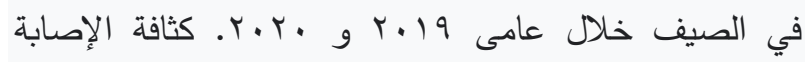
، بالهالوك Ph. aegyptiaca قسمت إلى ثلاث مستويات منخفض (1 - •1 شمراخ / نبات) ، متوسط (1) (1-ه بشمراخ / نبات) و عالي (

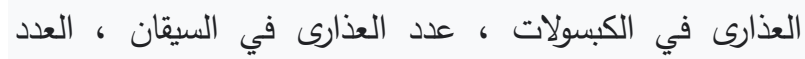
الإجمالي للعذارى في الشمراخ والنسبة المئوية للعذارى في لئي الكبسولات لكل شمراخ Ph. aegyptiaca. وسجل أعلى كفاءة من Ph. P. orobanchia aegyptiaca فقط ه, Ph. aegyptiaca

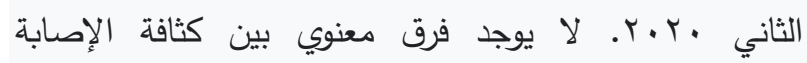
المنخفضة والمتوسطة من Ph. aegyptiaca في العدد الإجمالي لعذارى orobanchia . لكل شمراخ. 